\title{
Relationship between women's socioeconomic status and empowerment in Burkina Faso: A focus on participation in decision-making and experience of domestic violence
}

\author{
Madeleine WAYACK PAMBÈ*, Bilampoa GNOUMOU/THIOMBIANO and Idrissa \\ KABORÉ \\ Institut Supérieur des Sciences de la Population, Université de Ouagadougou
}

\begin{abstract}
Since 2009, the Burkina Faso government has launched a national policy to empower women and to better integrate gender equity in policies, actions, and programs. This paper explores how socioeconomic characteristics shape two aspects of women's empowerment: decision-making in the household and experience of domestic violence. Using binary logistic regression, data for 9, I4I cohabiting or married women from the 2010 Burkina Faso Demographic and Health Survey (DHS) are analyzed. Decision-making is positively associated with working for cash, education and higher household wealth. Women's experience domestic violence is weakly related to socioeconomic characteristics. Only psychological pressure is related to education and household wealth. The study show that high levels of human capital and financial autonomy influence women's participation in decision-making. The subtlety of the relationship between women's empowerment and domestic violence is also shown. In acceptance of traditional gender roles, neither education nor financial autonomy is sufficient to assert women's empowerment.
\end{abstract}

Keywords: women's empowerment; decision-making in the household; domestic violence; Burkina Faso; Sub-Saharan Africa

\section{Résumé}

Depuis 2009, le gouvernement Burkinabè a lancé une Politique Nationale Genre pour promouvoir l'autonomie des femmes et l'égalité entre les sexes. Cet article examine comment les caractéristiques socio-économiques des femmes influencent deux aspects de leur autonomie : la prise de décision au sein du ménage et le vécu de la violence domestique. Une régression logistique binaire a été appliquée à 9141 femmes mariées ou cohabitant avec un conjoint à l'Enquête Démographique et de Santé de 2010 (EDS) du Burkina Faso. La participation de la femme à la prise de décision est positivement associée à l'emploi rémunéré, l'éducation et le niveau de vie élevé du ménage. Concernant la violence domestique, seule la pression psychologique est associée à l'éducation et au niveau de vie du ménage. Le niveau élevé du capital humain et le revenu des femmes influencent leur participation à la prise de décision au sein du ménage. La relation entre les caractéristiques socio-économiques des femmes et la violence domestique parait complexe.

Mots clé: Participation des femmes à la prise de décision; violence domestique; statut socioéconomique des femmes; Burkina Faso; Afrique subsaharienne

\footnotetext{
${ }^{*}$ Corresponding author: Madeleine WAYACK PAMBÈ, Institut Supérieur des Sciences de la Population (ISSP), Université de Ouagadougou; mwayack@issp.bf ;wayack_madeleine@yahoo.fr
} 


\section{Introduction}

Since the late 1980s, the reduction of gender disparities has been of great concern for development policies, as highlighted in the third Millennium Development Goal. With this objective in mind, the Burkina Faso government launched in 2009 a national policy that aims at empowering women and better integrates gender equity in policies, actions, and programs. However, this policy lacks empirical evidence on women's empowerment, given the scarcity of research on this subject in Burkina Faso, reflecting the generally limited contribution of the sub-Saharan Africa region in the debate about empowerment in developing countries. Research on women's empowerment supports the view that it is a multidimensional, complex and context-specific issue (Charmes \& Wieringa 2003; Kabeer 2005). Therefore, what is valid in one region may not be valid for other regions, while socio-cultural systems vary considerably from one setting to another, and even within the same country.

It is necessary to study women's empowerment from the perspective of women's socioeconomic characteristics, as women are divided by heterogeneous categories based on class, life cycle, or ethnicity. This paper thus raises the question as to how socioeconomic factors shape two aspects of women's empowerment in the cultural and social context of Burkina Faso, namely decision-making in the household and experience of domestic violence. Reducing violence against women, as well as enhancing their capacity to decide for themselves, is important in empowering women. We aim to advance the understanding of women's empowerment in Burkina Faso to contribute to the government's efforts to mainstream the gender dimension into the country's development policies and programs.

\section{Literature review and theoretical framework}

\section{Literature review}

Burkina Faso, located in the West African region, is listed among the poorest countries in the world, and the development policy of the government is focused on poverty alleviation. This objective is impeded by serious handicaps, such as high fertility and infant mortality rates, as well as a low investment in human capital, especially among girls and women. A large portion of Burkina Faso's population is under age $15(46 \%)$ and lives in rural areas (74\%). In 2009 the gross enrolment ratio in tertiary education was $5 \%$ for men and $2 \%$ for women. Similarly the literacy rate for the population age 15 and older was higher for men (37\%) than for women (22\%) (UNESCO 20I0; UNESCO 20II). The Burkinabe government has to tackle these issues from a gender equity and women's empowerment perspective.

Available studies in different settings on the relationship between socioeconomic factors and women's status report reasons to expect variations in the effects of women's socioeconomic characteristics on different aspects of their life. For example, while some studies indicate that poverty is a strong predictor of domestic violence, others show that it is an insignificant factor (Kishor \& Johnson 2006). Literature usually reports higher socioeconomic status, namely women's increasing education and participation in wage work, to be positively related with women's greater say on decision-making in the household (Acharya \& al. 2010; Furuta \& Salway (2006)). In Ghana, wealthier women were found to be more likely than poorer women to be involved in decision-making on their own health care, while employed and educated women were more likely to have a say in all aspects of the decision-making in their household, relative to unemployed women and women with no formal education (Boateng \& al. 20I2).

As for domestic violence, some studies show that this phenomenon varies considerably according to social strata. For example, women in the highest wealth quintiles are found to be less likely than those in the poorest quintiles to have experienced physical violence, as are educated women or women with a highly educated partner (Naved \& Persson 2008; Koenig \& al. 2003).

Studies also suggest that sources of women's empowerment could be compounding factors for risk of spousal violence (Kocacik \& al. 2007; Wandera, Ntozi and Kwagala 2010). While both education and employment might enable women to challenge traditional male authority and control, in doing so, women would thereby set the stage for greater marital tension and conflict, which in turn could lead to domestic violence (Kaye \& al. 2005). Nevertheless qualitative study among wealthy, well educated, and employed Ghanaian women found that neither education nor paid employment prevented women from experiencing domestic violence (Amoakohene 2004).

These inconsistent effects of socioeconomic factors on different aspects of women's empowerment demonstrate the need to look 
closely at the mechanisms through which women's socioeconomic characteristics affect both decisionmaking and domestic violence in the household. The present study seeks to understand how socioeconomic factors are part of the explanation for women's empowerment in households in Burkina Faso. Women's empowerment can be understood at different levels, individual and social, in different dimensions, and within the intimate family setting or in the public domain (Charmes \& Wieringa 2003; Cueva Beteta 2006). We focus on women's empowerment at the individual and household levels, as they are important levels in which empowerment occurs, and central to the determination of women's disempowerment.

\section{Theoretical framework}

Women's empowerment focuses on individual and collective aspects of power, yet it remains a fuzzy concept, and there is still considerable debate about its meaning and measurement (Calvès 2009; Kabeer 2005). Many authors conceptualize empowerment less as an outcome and more as a process, i.e. a progress from the state of gender inequality to the state of gender equality. As such, empowerment is composed of elements that enable or limit it (Cueva Beteta 2006; Kabeer 2005; Kishor 2000). According to Kishor (2000), indicators of women's empowerment as agency or end-result, i.e. evidence, should directly measure women's control over their lives or environment, while indicators of process should document the existence or absence of an appropriate setting for empowerment and women's access to different sources of empowerment. The theoretical framework of this study is based on Kishor's proposed operationalization of women's empowerment.

It views participation in household decisionmaking as evidence of empowerment, and domestic violence as an indicator of the setting for empowerment. Specifically, knowing whether a woman has or has not experienced intimate partner violence should tell us something about the ability of her household to promote her empowerment (Kishor, 2000). Knowing whether or not she has a say in decision-making tells us something about the extent to which she is already empowered within the household.

Firstly, we expect to find that the three socioeconomic indicators examined in this paper are each associated with decision-making and domestic violence outcomes. Women's level of education would be positively associated with their participation in household decision-making, and conversely associated with their experience of domestic violence. Secondly, we hypothesize that women employed for cash will have more say in household decisions and are less likely to experience domestic violence. Lastly, we assume that women in poor households would be more likely than those in richer households to experience domestic violence and less likely to have a say in household decisions.

\section{Data and methods}

Data

Data for the analysis are drawn from the 2010 Burkina Faso Demographic and Health Survey $\left(B F D H S^{\prime}\right)$, a national-level population and health survey conducted by the Institut National de la Statistique et de la Démographie of Burkina Faso (INSD), in close collaboration with other stakeholders in various sectors of government, and international partners (USAID, ICF, UNFPA, UNICEF). The 2010 BFDHS sample is representative of urban and rural areas in the 13 regions in the country.

The survey identified 17,363 women age 15-49 from 14,424 households, of which 17,087 women were interviewed, for a response rate of $98 \%$ (INSD \& ICF, 20I2). The BFDHS 2010 provides information on participation in decision-making and domestic violence, among other things, in Burkina Faso. Our research focuses on women who were currently married or living with a partner and who successfully completed the interview on domestic violence, yielding a sample size of $9,14 \mathrm{I}$.

\section{Key Variables}

The two outcome variables analyzed in this study are women's participation in decision-making and women's report of their experience of domestic violence. Women's participation in decision-making was assessed through three types of household decision-making: woman's own health care, major household purchases, and visits to family or relatives. For each of these three dimensions of decision-making, women are asked who usually makes the decisions. Each question had five response options: respondent alone, respondent and husband/partner, husband/partner alone; someone else; and others. We created a binary variable for each type of decision-making by grouping together the first two responses in which women participate in decision-making, coded as I, and other responses together in which she has no say in decision-making, coded as 0 .

In the DHS domestic violence module, women were asked a series of questions about their 
experience of domestic violence by husband/partner, i.e. physical (if the respondent has ever been: pushed, shook or had something thrown at; slapped; punched with fist or hit by something harmful; kicked or dragged; strangled or burnt; threatened with a weapon); emotional (if the respondent has ever been humiliated or threatened with harm) and sexual violence (if the respondent has ever been physically forced into unwanted sex or other unwanted sexual acts).

Each question has four responses for married women: never, often, sometimes, yes but not in the last 12 months. In this study, we considered experience of domestic violence within the last 12 months prior to the survey. Women reporting that they experienced violence "often" or "sometimes" were categorized as having experienced domestic violence in the last 12 months and coded as I, and other responses were categorized as no experience of domestic violence in the last 12 months and coded as 0 . Another variable - psychological pressure - was also computed based on women's responses to a series of questions included in the domestic violence module and related to husband/partner behaviour: jealousy; accusation of unfaithfulness, prohibition to meet female friends; limitation of contact with family; distrustful with money, prevents her from working). If a woman responded "yes" to any of the seven questions, she was considered to face psychological pressure from her husband/partner.

The key independent variables used in the study are women's own education, participation in paid work, and household wealth status. Women's education is coded into three categories: not educated, primary level, secondary level or more. Paid work includes three categories: not working, not paid (paid in kind/work without payment), cash paid.

Wealth status is categorized in quintiles: poorest, poor, middle, richer, richest. The wealth quintiles are constructed using information on household ownership of consumer items. This recoded variable is included in the BFDHS-MICS 2010 data provided by Measure DHS.

\section{Statistical Analysis}

We used chi-squared tests to assess the statistical significance of the differences among women and binary logistic regression for the multivariate analysis. A binary logistic regression model is used when the dependent variable is dichotomous such as participation in decision-making and experience domestic violence (Fox 1999). Logistic regression provides odds ratios, which represent the ratio of two probabilities: the probability that the event occur $(P)$ and the probability that it does not occur $(I-P)$. The odds ratio is interpreted in terms of deviation from a reference category.

For women's participation in decision-making, we ran three separate models, one for each of the three variables. For the four domestic violence outcomes - physical violence, sexual violence, emotional violence, and psychological pressure, separate logistic regression models were fitted to examine their association with women's socioeconomic characteristics. A number of sociodemographic and cultural variables were controlled for in the regressions, including women's age, spousal age difference, religion, ethnicity and area of residence.

\section{Results}

\section{Descriptive analysis}

Table I provides information on demographic and socioeconomic characteristics of women included in the study, as well as descriptive statistics on their participation in household decision- making and experience of domestic violence in the last 12 months. The vast majority of women are much more likely to live in rural areas, to be uneducated, polarized between those who are paid cash for work and those who are not paid, and according to household wealth status, divided between those who are in the poorest or poorer quintiles, and those who are in the richer or richest quintiles.

Women's participation in household decision-making

Analysis of women's participation in decisionmaking shows that overall, $12 \%$ of the women participate in all three areas of decision-making, and $59 \%$ in at least one of the three aspects. However, while $52 \%$ participate in decisions for visiting their family, only $24 \%$ and $21 \%$ participate in decisions for their own health and important purchases, respectively. Women with more education are more likely to participate in all three types of household decisions, similar to women who work for pay and women from the wealthiest household quintile. The older the women, the more they participate in household decisions, except for family visits. Also, the greater the age differences between spouses, the lower the women's involvement in decisionmaking. Christian women are more likely to make decisions for their own health. Lobi/Dagara (49\%) and Gourounsi (37\%) women are more involved in decision-making for their own health care, and Gourounsi (43\%) and Bobo/Dioula (28\%) women 
are more empowered in making household purchasing decisions. Women in rural areas are less likely to participate in making all the three types of household decisions.

Women's experience of domestic violence

As to women's experience of domestic violence, it seems that psychological pressure is much more widely reported than the other three forms of violence. While only $7 \%$ of surveyed women reported emotional violence, $8 \%$ physical violence, and $1 \%$ sexual violence occurring in the past 12 months, $61 \%$ reported psychological pressure. Educated women report more psychological pressure, as well as women who do not have paid work, younger women and Muslim ones.

When considering physical violence and emotional violence, women with education, women who work, and older women are more likely to report these forms of domestic violence, while Muslim women are least likely to report them. There are no significant differences in reporting either psychological pressure or emotional or physical violence by place of residence. Sexual violence does not show clear patterns by socioeconomic status and background characteristics. 
Table I: Percent distribution of women who participate in the decision-making and who experienced various forms of domestic violence by measures of socioeconomic status and background characteristics.

\begin{tabular}{|c|c|c|c|c|c|c|c|c|c|}
\hline \multirow[b]{2}{*}{ Charateristics } & \multirow[b]{2}{*}{ Percent } & \multicolumn{3}{|c|}{ Decision-making } & \multicolumn{4}{|c|}{ Domestic violence } & \multirow[b]{2}{*}{$\begin{array}{l}\text { Number } \\
\text { of } \\
\text { women }\end{array}$} \\
\hline & & $\begin{array}{l}\text { Woman's own } \\
\text { Health care }\end{array}$ & $\begin{array}{c}\text { Making major } \\
\text { household } \\
\text { purchases }\end{array}$ & $\begin{array}{l}\text { Visits to Family } \\
\text { or relaties }\end{array}$ & $\begin{array}{l}\text { Psychological } \\
\text { pressure }\end{array}$ & $\begin{array}{c}\text { Emotional } \\
\text { violence }\end{array}$ & $\begin{array}{l}\text { Physical } \\
\text { violence }\end{array}$ & $\begin{array}{c}\text { Sexual } \\
\text { violence }\end{array}$ & \\
\hline \multicolumn{10}{|l|}{ Socioeconomic status } \\
\hline \multicolumn{10}{|l|}{ Education } \\
\hline No education & 82.3 & 21.1 & 17.8 & 50.5 & 59.5 & 6.5 & 8.3 & 1.0 & 7,525 \\
\hline Primary & 10.7 & 30.7 & 27.3 & 55.6 & 67.0 & 10.0 & 11.6 & 1.6 & 979 \\
\hline Secondary and more & 7.0 & 48.0 & 43.1 & 66.6 & 71.6 & 10.5 & 9.9 & 1.3 & 638 \\
\hline \multicolumn{10}{|l|}{ Paid work } \\
\hline Not work & 18.0 & 14.4 & 15.4 & 50.2 & 70.1 & 5.2 & 7.1 & 0.8 & 1,645 \\
\hline Not paid & 43.8 & 16.8 & 14.3 & 48.1 & 58.3 & 6.3 & 8.0 & 1.2 & 4,002 \\
\hline Cash paid & 38.2 & 36.7 & 30.2 & 57.7 & 60.2 & 9.1 & 10.5 & 1.2 & 3,494 \\
\hline \multicolumn{10}{|l|}{ Wealth index } \\
\hline Poorest & 18.9 & 20.5 & 18.4 & 50.1 & 55.8 & 7.5 & 7.3 & 0.7 & 1,725 \\
\hline Poorer & 20.3 & 18.9 & 17.1 & 47.5 & 60.7 & 6.9 & 9.1 & 1.5 & 1,857 \\
\hline Middle & 20.6 & 20.2 & 16.4 & 47.2 & 58.7 & 5.3 & 7.7 & 0.9 & 1,88 \\
\hline Richer & 20.8 & 23.2 & 19.0 & 52.7 & 62.4 & 6.4 & 9.0 & 1.2 & 1,903 \\
\hline Richest & 19.4 & 37.7 & 32.2 & 63.7 & 68.1 & 10.0 & 10.7 & 1.4 & 1,776 \\
\hline \multicolumn{10}{|l|}{ Background characteristics } \\
\hline \multicolumn{10}{|l|}{ Age } \\
\hline $15-19$ & 7.7 & 15.5 & 14.6 & 47.0 & 63.5 & 4.1 & 3.7 & 0.4 & 705 \\
\hline $20-24$ & 19.4 & 21.7 & 20.0 & 52.4 & 71.3 & 7.3 & 9.4 & 1.9 & 1,772 \\
\hline $25-29$ & 20.2 & 24.5 & 21.0 & 53.7 & 63.7 & 7.6 & 9.3 & 0.7 & 1,842 \\
\hline $30-34$ & 18.1 & 23.9 & 20.4 & 53.4 & 59.0 & 7.6 & 8.3 & 0.9 & 1,652 \\
\hline $35-39$ & 14.4 & 24.9 & 22.5 & 51.7 & 58.8 & 7.7 & 10.6 & 1.6 & 1,319 \\
\hline $40-44$ & 11.5 & 27.3 & 19.6 & 50.9 & 56.2 & 8.0 & 9.0 & 0.6 & 1,056 \\
\hline $45-49$ & 8.7 & 29.9 & 24.2 & 52.8 & 45.5 & 5.7 & 8.5 & 1.5 & 796 \\
\hline \multicolumn{10}{|c|}{ Husband-wife age difference } \\
\hline Less than 5 years & 20.9 & 28.5 & 25.6 & 54.0 & 62.6 & 9.2 & 11.4 & 1.6 & 1,907 \\
\hline $5-9$ years & 33.1 & 23.5 & 21.2 & 53.5 & 61.7 & 6.9 & 9.2 & 1.3 & 3,03 \\
\hline $10-14$ years & 20.6 & 24.1 & 20.6 & 51.4 & 59.9 & 7.4 & 8.5 & 0.8 & 1,886 \\
\hline 15 years and more & 24.8 & 20.6 & 15.4 & 49.5 & 60.6 & 5.8 & 6.3 & 0.8 & 2,265 \\
\hline Undetermined & 0.6 & 28.3 & 18.9 & 52.8 & 41.5 & 3.8 & 3.8 & & 53 \\
\hline \multicolumn{10}{|l|}{ Religion } \\
\hline Muslim & 63.6 & 19.6 & 17.1 & 48.8 & 63.1 & 5.3 & 7.2 & 0.8 & 5,816 \\
\hline No religion & 1.0 & 24.0 & 28.4 & 52.7 & 56.0 & 14.9 & 14.7 & - & 93 \\
\hline Catholic & 21.3 & 33.3 & 28.4 & 55.1 & 59.2 & 8.3 & 9.9 & 1.6 & 1,945 \\
\hline Protestant & 5.9 & 32.0 & 29.4 & 62.3 & 58.2 & 9.5 & 10.4 & 1.9 & 538 \\
\hline Traditional/animist & 8.2 & 28.5 & 20.2 & 63.6 & 53.5 & 16.2 & 16.3 & 2.3 & 748 \\
\hline \multicolumn{10}{|l|}{ Ethnicity } \\
\hline Mossi & 51.1 & 23.6 & 19.5 & 48.1 & 60.1 & 5.3 & 6.8 & 0.9 & 4,675 \\
\hline Bobo/Dioula & 5.7 & 26.8 & 28.1 & 67.1 & 70.8 & 12.7 & 20.2 & 2.3 & 519 \\
\hline Fulfuldé / Peul & 9.4 & 14.4 & 14.3 & 34.6 & 66.4 & 2.9 & 3.3 & 0.3 & 860 \\
\hline Gourmatché & 7.5 & 20.6 & 17.7 & 79.4 & 44.5 & 6.0 & 6.0 & 0.4 & 683 \\
\hline Gourounsi & 4.6 & 37.0 & 43.3 & 37.8 & 58.0 & 7.4 & 8.1 & 0.5 & 418 \\
\hline Lobi/Dagara & 4.7 & 49.4 & 24.7 & 66.3 & 63.3 & 22.7 & 18.1 & 3.2 & 431 \\
\hline Sénoufo & 4.5 & 13.1 & 15.1 & 62.6 & 60.2 & 11.4 & 15.5 & 2.7 & 412 \\
\hline Touareg / Bella & 2.0 & 5.3 & 9.7 & 44.1 & 80.6 & 7.5 & 7.5 & & 187 \\
\hline Bissa & 3.7 & 25.2 & 12.9 & 44.7 & 59.1 & 7.9 & 7.1 & 1.5 & 340 \\
\hline Others & 6.7 & 27.4 & 26.4 & 64.0 & 68.7 & 9.7 & 16.0 & 1.5 & 617 \\
\hline \multicolumn{10}{|l|}{ Type of place of residence } \\
\hline Urban & 21.1 & 35.5 & 30.0 & 60.2 & 65.2 & 10.3 & 10.8 & 1.6 & 1,927 \\
\hline Rural & 78.9 & 20.9 & 18.0 & 50.0 & 60.1 & 6.3 & 8.2 & 1.0 & 7,215 \\
\hline Total & 100.0 & 24.0 & 20.5 & 52.2 & 61.1 & 7.2 & 8.8 & 1.1 & 9,141 \\
\hline
\end{tabular}

NB: Except for sexual violence which showed no statistically significant relationship with our three key variables (education, paid work, wealth quintiles), all Pearson Chi-squared test were significant at the 95\% level.

Source: Author's calculations from BFDHS 2010

\section{Multivariate analysis}

The regressions in Table 2 focus on the determinants of both the three aspects of decisionmaking and domestic violence and for psychological pressure. The results present the adjusted associations between each of the three measures of socioeconomic status and each of the aspects of the two outcomes variables, after controlling for key characteristics that could confound the association. Conditional on these key background variables, we see that each of the three key measures of socioeconomic status is significantly associated with at least two of the three forms of decision-making. The odds of participating in each type of decision- 
making appear higher among educated women. Women who are paid for work have higher odds of participating in the three types of decision-making, compared with women who are not paid for work. The odds of participating in decisions for their own health care and for large household purchases are highest among women living in the richest household quintile, but wealth status does not have a significant association with decisions concerning family visits. The results also highlight women's age as an important determinant of household decisionmaking. Older women are more likely to participate in decision-making. Findings do not reveal significant differences between women by spousal age difference and place of residence.

Socioeconomics determinants of domestic violence

Of the three measures of socioeconomic status, two (education and wealth quintiles) are significantly associated with women's experience of a form of violence, and this association is significant only for psychological pressure. After adjusting for control variables, women with secondary or higher education have greater odds of experiencing psychological violence than women with no education. Similarly, wealth status' effect is significant for psychological pressure but not for the other domestic violence outcomes. The odds of experiencing psychological pressure appear also highest among women in the richest household quintile. As for background variables, compared to women aged 35-39, older women (40 and above) are less likely to experience psychological violence whereas young women (15-19) are more likely to have such experience. Animist women are more likely to experience emotional and physical violence than Muslim women. For other types of domestic violence, the differences are not statistically significant. As regards ethnicity, the odds of experiencing psychological pressure, emotional violence, and physical violence are higher among Lobi/Dagara and Bobo/Dioula women than Mossi women. Gourmantché women are less likely to experience psychological pressure than Mossi women, while Toureg/Bella women are more likely to experience it. The differences are not significant for urban-rural residence, except that the odds of experiencing emotional violence are greatest for rural women. 
Table 2: Adjusted associations between measures of socioeconomic status and women's participation in household decision-making, and women's experience of domestic violence, among married/cohabitating women who completed the domestic violence module, Burkina Faso 2010

\begin{tabular}{|c|c|c|c|c|c|c|c|}
\hline \multirow[b]{2}{*}{ Characteristics } & \multicolumn{3}{|c|}{ Decision-making } & \multicolumn{4}{|c|}{ Domestic violence } \\
\hline & $\begin{array}{c}\text { Woman's own } \\
\text { Health care }\end{array}$ & $\begin{array}{c}\text { Making major } \\
\text { household } \\
\text { purchases }\end{array}$ & $\begin{array}{l}\text { Visits to } \\
\text { Family or } \\
\text { relaties }\end{array}$ & $\begin{array}{l}\text { Psychological } \\
\text { pressure }\end{array}$ & $\begin{array}{l}\text { Emotional } \\
\text { violence }\end{array}$ & $\begin{array}{l}\text { Physical } \\
\text { violence }\end{array}$ & $\begin{array}{c}\text { Sexual } \\
\text { violence }\end{array}$ \\
\hline \multicolumn{8}{|l|}{ Socioeconomic status } \\
\hline \multicolumn{8}{|l|}{ Education } \\
\hline No education (Reference) & 1.00 & 1.00 & 1.00 & 1.00 & 1.00 & 1.00 & 1.00 \\
\hline Primary & $1.27^{* *}$ & 1.02 & $1.29 * *$ & $1.21 *$ & 1.27 & 1.13 & 1.14 \\
\hline Secondary and more & $1.97 * * *$ & $1.30 *$ & $2.04 * * *$ & $1.43 * *$ & 1.08 & 0.83 & 0.75 \\
\hline \multicolumn{8}{|l|}{ Paid work } \\
\hline Not paid (Reference) & 1.00 & 1.00 & 1.00 & 1.00 & 1.00 & 1.00 & 1.00 \\
\hline Cash paid & $2.39 * * *$ & $1.38 * * *$ & 2.22 *** & 0.91 & 1.10 & 1.20 & 0.81 \\
\hline Not work & 0.80 & 1.19 & 1.03 & 1.29 & 0.78 & 0.97 & 0.71 \\
\hline \multicolumn{8}{|l|}{ Wealth index } \\
\hline Poorest (Reference) & 1.00 & 1.00 & 1.00 & 1.00 & 1.00 & 1.00 & 1.00 \\
\hline Poorer & 0.98 & 1.03 & 0.90 & 1.15 & 1.05 & 1.30 & 2.09 \\
\hline Middle & 1.13 & 1.06 & 0.91 & 1.09 & 0.83 & 1.12 & 1.24 \\
\hline Richer & 1.20 & $1.30 * *$ & 0.96 & $1.26 *$ & 0.90 & 1.18 & 1.47 \\
\hline Richest & 1.60 ** & $1.83^{* * *}$ & 1.27 & $1.57 * * *$ & 1.08 & 1.22 & 1.31 \\
\hline \multicolumn{8}{|l|}{ Background characteristics } \\
\hline \multicolumn{8}{|l|}{ Age } \\
\hline 35-39 (Reference) & 1.00 & 1.00 & 1.00 & 1.00 & 1.00 & 1.00 & 1.00 \\
\hline $15-19$ & 1.31 & 1.20 & 1.27 & $1.44 * * *$ & $1.77 *$ & $2.56 * * *$ & $3.93 * *$ \\
\hline $20-24$ & $1.49 * *$ & $1.28 *$ & $1.33^{*}$ & 1.04 & $1.78 * *$ & $2.49 * * *$ & 1.37 \\
\hline $25-29$ & $1.39 *$ & $1.29 *$ & 1.26 & 0.86 & $1.73 *$ & $2.20 * * *$ & 1.89 \\
\hline $30-34$ & $1.46 *$ & 1.21 & $1.42 *$ & 0.86 & $1.69 *$ & $2.79 * * *$ & $3.12 *$ \\
\hline $40-44$ & $1.73 * * *$ & 1.15 & 1.18 & $0.75 *$ & $1.78 *$ & $2.24 * *$ & 1.22 \\
\hline $45-49$ & $2.06 * * *$ & $1.33^{*}$ & 1.69 *** & $0.49 * * *$ & 1.22 & $2.22 * *$ & 2.87 \\
\hline \multicolumn{8}{|l|}{ Husband-wife age difference } \\
\hline Less than 5 years (Reference) & 1.00 & 1.00 & 1.00 & 1.00 & 1.00 & 1.00 & 1.00 \\
\hline $5-9$ years & $0.84 *$ & 1.03 & 0.86 & 0.97 & 0.79 & 0.87 & 0.89 \\
\hline 10-14 years & 0.97 & 1.00 & 0.91 & 0.95 & 0.91 & 0.84 & 0.64 \\
\hline 15 years and more & $0.82 *$ & 0.98 & $0.66^{* * *}$ & 1.05 & 0.77 & $0.64 * *$ & 0.59 \\
\hline Undetermined & 1.46 & 1.09 & 1.00 & $0.47 *$ & 0.46 & 0.41 & - \\
\hline \multicolumn{8}{|l|}{ Religion } \\
\hline Muslim (Reference) & 1.00 & 1.00 & 1.00 & 1.00 & 1.00 & 1.00 & 1.00 \\
\hline No religion & 1.00 & 0.78 & 1.39 & 0.93 & $2.90 * *$ & 1.83 & - \\
\hline Catholic & $1.41 * * *$ & 1.00 & 1.38 *** & 0.91 & 1.26 & 1.16 & 1.79 \\
\hline Protestant & $1.52 * * *$ & 0.94 & 1.57 **** & 0.96 & 1.58 & 1.24 & 2.30 \\
\hline Traditionnal/animist & 1.23 & 1.10 & 1.25 & 0.81 & $2.21 * * *$ & $1.83 * * *$ & 2.31 \\
\hline \multicolumn{8}{|l|}{ Ethnicity } \\
\hline Mossi (Reference) & 1.00 & 1.00 & 1.00 & 1.00 & 1.00 & 1.00 & 1.00 \\
\hline Bobo/Dioula & 0.83 & $2.06 * * *$ & 1.15 & $1.69 *$ & $1.92 * *$ & $2.72 * * *$ & 1.82 \\
\hline Fulfuldé / Peul & $0.61 * *$ & $0.59 * * *$ & 0.71 & $1.37 *$ & 0.65 & $0.50 *$ & 0.54 \\
\hline Gourmatché & 0.84 & $4.93 * * *$ & 0.80 & $0.61 * * *$ & 0.90 & 0.78 & 0.43 \\
\hline Gourounsi & $1.62 *$ & 0.65 & $2.71 * * *$ & 0.98 & 1.12 & 1.03 & 0.45 \\
\hline Lobi/Dagara & 2.34 *** & 1.99 *** & 0.91 & $1.55 *$ & $3.30 * * *$ & $2.07 * * *$ & 2.44 \\
\hline Sénoufo & 0.50 *** & $1.86^{* * *}$ & 0.78 & 1.01 & $2.18 * * *$ & $2.28 * * *$ & $2.48 *$ \\
\hline Touareg / Bella & $0.28 *$ & 0.98 & 0.61 & $2.74 * * *$ & 2.29 & 1.44 & - \\
\hline Bissa & 1.09 & 0.87 & $0.59 * *$ & 0.97 & $1.57 *$ & 1.02 & 1.47 \\
\hline Others & 1.03 & $1.77^{* * *}$ & 1.25 & $1.48 * *$ & $1.73 * *$ & $2.36 * * *$ & 1.36 \\
\hline \multicolumn{8}{|l|}{ Type of place of residence } \\
\hline Urban (Reference) & 1.00 & 1.00 & 1.00 & 1.00 & 1.00 & 1.00 & 1.00 \\
\hline Rural & 0.99 & 1.08 & 1.05 & 1.18 & $0.62 * * *$ & 0.82 & 0.56 \\
\hline
\end{tabular}

NB: Significance $*=5 \% ; * *=1 \% ; * * *=1 \%$. 


\section{Discussion and conclusion}

This paper focuses on the relationship between women's socioeconomic characteristics and their empowerment in the household (participation in decision-making in the couple and experience of domestic violence) in Burkina Faso. By showing that high levels of education and financial autonomy greatly influence women's participation in decisionmaking, our analysis is consistent with previous studies on women's decision-making in other countries Boateng \& al., 2012; Acharya \& al., 2010). Yet, while our study raises many questions, it provides few answers regarding the relationship between women's socioeconomic status and domestic violence.

Consistent with Boateng \& al. (2012) and Acharya \& al. (2010), and also supporting our first hypothesis, we found that relative to women with no formal education, women with some education are more likely to be involved in decision-making. It could be that educated women are likely to be better in terms of knowledge to negotiate their participation in household decisions, and to some extent also because they are in a better position to have paid work. Similarly, our findings reveal that having paid employment is also a factor positively and significantly associated with women's greater say on all aspects of household decision-making, supporting our second hypothesis. Women who are paid for work might be better able to make their case in household bargaining, as they have the means of contributing to supporting the costs related to their own health care as well as in major purchases. The results also support our hypothesis that the poorest women would be less involved in decisionmaking.

Conversely, the key indicators of socioeconomic factors considered in the study were statistically significant related to domestic violence, which contradicts our initial hypothesis. More specifically, domestic violence is not related to women's level of education, to their participation to paid labour and to household wealth index. Only psychological pressure is related to education and household wealth. Women with more education and the richest group of women are more likely than noneducated or the poorest group of women to report psychological pressure. The finding of higher reporting of psychological violence for the most educated women corroborates findings from studies in other settings (Amoakohene 2004; Yount \& Carrera, 2006). One explanation of this result could be that husbands threatened by their wives' level of education may use non-physical violence to assert their dominance, as more highly educated wives may be better able to prevent physical abuse (Yount \& Carrera, 2006).

Similarly, our study does not find cash-paid work to be associated with domestic violence. It could be that women in Burkina Faso are still reluctant to challenge their husbands' authority, regardless of their financial contribution to household wealth.

We also found some of our control variables to be significantly associated with two of our empowerment outcome variables. Age is strongly associated with women's participation in decisionmaking with regard to their own health care and family visiting. Women may gain authority as they age, which could also explain why the older women in the study were less likely than the younger women to report psychological pressure. Consistent with previous studies, we also found that the younger women are more likely than older women to report domestic violence (Frias \& Angel 2005; Weaver \& al. 1997). All in all, considering both types of outcome variables included in this research, decision-making and domestic violence, it appears that although education and employment play key roles as resources that enhance women's bargaining ability in the couple, they are not sufficient in asserting women's empowerment. Also, those factors tell very little about domestic violence, which is not widely reported in Burkina Faso (9.4\% according to BFDHS 2010 report figures), in contrast with what is generally said about this issue in African countries (Appiah\& Cusack 1999, cited by Amoakohene 2004; Bowman 2003; Jewkes\& al. 2002). It could be that the socioeconomic factors included in this study are more closely related to women's decision-making, than to domestic violence. The overall findings of this study raises questions about the poor link between domestic violence and socioeconomic status and the low prevalence of reported domestic violence in Burkina Faso. Factors surrounding women's empowerment form part of the causes of domestic violence. Whatever their level of education or contribution to household wealth, having a conjugal home is a central issue for women in Burkina Faso (Attané 2009; Bertho 2012). It might be that regardless of the level of education and financial contribution to household wealth, women in Burkina Faso are respectful of the traditional gender norms and consequently might not dispute the authority of the husband as chief of the family, what glaringly 
contributes to an apparent harmony in couples relationships.

One of the major concern highlighted by this study is that domestic violence in Burkina Faso might be under-reported because of cultural norms, among other reasons. Women might be reluctant to disclose intimate issues to strangers, as it is badly perceived in Burkinabe society (Randall \& al. 20l3). Some studies have also found that the estimated prevalence of domestic violence is lower in the DHS than in focused surveys (Ellsberg \& al. 200I). Other caveat might be that DHS data are cross-sectional and therefore do not help capture causal relationships between explanatory factors and main outcome variables.

This study adds an insight into the understanding of women's empowerment in Burkina Faso, where to our knowledge there is a scarcity of studies on this issue. Our findings confirm the major role of education for improving women's status in terms of participation in the decision-making in the household. It provides thus additional arguments for the continuity of actions in favour of girl's education at higher levels of schooling in addition to the primary level. The development of national policies and programs aiming to substantially increase women's status in Burkina Faso should foster positive socio-cultural attitudes toward gender equality.

\section{Acknowledgments}

This study was funded by the United States Agency for International development (USAID), with a technical assistance from ICF International through the DHS fellow program. Special thanks are due to Kerry MacQuarrie, Sarah Staveteig and Wenjuan Wang. Rebecca Winter provided insightful comments. Ambrose Akinlo and fellows of the 2013 DHS fellow program provided valuables remarks. Our thanks to the two anonymous referees for their useful comments on an earlier draft of the paper

\section{Author's contribution}

MWP designed the study, wrote the introduction, literature review and theoretical framework, discussion and conclusion. BG wrote the data and methods, performed the multivariate analysis. IK performed the descriptive analysis, wrote the results. All the three authors designed the methodology, revised and approved the final manuscript.

\section{References}

Acharya, D.R., J.S. Bell, P. Simkhada, E.R.v. Teijlingen, and P.R. Regmi. 2010. "Women's autonomy in household decision-making: A demographic study in Nepal." Reproductive Health 7(15).

Amoakohene, M.I. 2004. "Violence against women in Ghana: a look at women's perceptions and review of policy and social responses." Social Science \& Medicine 59( I I):2373-2385.

Attané, A. 2009. "Se marier à Ouahigouya: argent et mutations des rapports sociaux de sexe, d'âge et de génération au Burkina Faso." pp. 25-46 in La valeur des liens. Hommes, femmes et transactions familiales, edited by A. Martial. Toulouse: Editions des Presses Universitaires du Mirail, collection Les anthropologiques.

Bertho, B. 2012. "Trajectoires et revendications féminines dans le règlement des différends conjugaux autour de deux études de cas en milieu Mossi (Burkina Faso)." Autrepart 2(6I):99II 5.

Boateng, G.O., V.Z. Kuuire, M. Ung, J.A. Amoyaw, F.A. Armah, and I. Luginaah. 20I2. "Women's Empowerment in the Context of Millennium Development Goal 3: A Case Study of Married Women in Ghana." Social Indicators Research:I22.

Bowman, C.G. 2003. "Domestic violence: Does the African context demand a different approach?" International Journal of Law and Psychiatry 26:473491.

Calvès, A.-E. 2009. "«Empowerment»: généalogie d'un concept clé du discours contemporain sur le développement." Revue Tiers Monde 4(200):735749.

Charmes, J. and S. Wieringa. 2003. "Measuring Women's Empowerment: An assessment of the Gender-related Development Index and the Gender Empowerment Measure." Journal of Human Development 4(3):419-435.

Cooper, H. 2002. "Investigating socio-economic explanations for gender and ethnic inequalities in health." Social Science \& Medicine 54(5):693-706.

Cueva Beteta, H. 2006. "What is missing in measures of women's empowerment?" Journal of Human Development 7(2):22I-24l.

Ellsberg, M., L. Heise, R. Pena, S. Agurto, and A. Winkvist. 200I. "Researching Domestic Violence Against Women: Methodological and Ethical Considerations." Studies in Family Planning 32(I): I- 16.

Frias, S.M. and R.J. Angel. 2005. "The Risk of Partner Violence among Low-Income Hispanic Subgroups." Journal of Marriage and Family 67(3):552-564. 
Fox W. 1999. "Statistiques sociales." Les Presses de l'Université Laval de Boeck Université, 374 p.

Furuta, M. and S. Salway. 2006. "Women's Position Within the Household as a Determinant Of Maternal Health Care Use in Nepal." International Family Planning Perspectives 32(I): 17-27.

llika, A.L. 2005. "Women's Perception of Partner Violence in a Rural Igbo Community." African Journal of Reproductive Health / La Revue Africaine de la Santé Reproductive 9(3):77-88.

Institut National de la Statistique et de la Démographie (INSD) et ICF International, 2012. Enquête Démographique et de Santé et à Indicateurs Multiples du Burkina Faso 2010. Calverton, Maryland, USA: INSD et ICF International

Jewkes, R., J. Levin, and L. Penn-Kekana. 2002. "Risk factors for domestic violence: findings from a South African cross-sectional study." Social Science \& Medicine 55(9): 1603-1617.

Kabeer, N. 2005. "Gender Equality and Women's Empowerment: A Critical Analysis of the Third Millennium Development Goal." Gender and Development 13(1):13-24.

Kaye, D.K., F. Mirembe, A.M. Ekstrom, G. Bantebya, and A. Johansson. 2005. "The Social Construction and Context of Domestic Violence in Wakiso District, Uganda." Culture, Health \& Sexuality 7(6):625-635.

Kishor, S. 2000. "Empowerment of women in Egypt and links to the survival and health of their infants." Pp. I19-156 in Women's empowerment and demographic processes: Moving beyond Cairo, edited by H.B. Presser and G. Sen. New York: Oxford University Press.
Kishor, S. and K. Johnson. 2006. "Reproductive Health and Domestic Violence: Are the Poorest Women Uniquely Disadvantaged?" Demography 43(2):293-307.

Kocacik, F., A. Kutlar, and F. Erselcan. 2007. "Domestic violence against women: A field study in Turkey." The Social Science Journal 44(4):698720.

Koenig, M.A., S. Ahmed, M.B. Hossain, and A.B.M.K.A. Mozumder. 2003. "Women's Status and Domestic Violence in Rural Bangladesh: Individual- and Community-Level Effects." Demography 40(2):269-288.

Naved, R.T. and L.A. Persson. 2008. "Factors Associated with Physical Spousal Abuse of Women During Pregnancy in Bangladesh." International Family Planning Perspectives 34(2):7I-78.

Randall, S., E. Coast, N. Compaore, and P. Antoine. 2013. "The power of the interviewer." Demographic Research 28(27):763-792.

UNESCO. 2010. "Tendances dans l'enseignement supérieur: I'Afrique subsaharienne." p. 7 in Bulletin d'information de I'ISU.

UNESCO Institute for Statistics. 201I. "Global education digest 2011. Comparing Education Statistics Across The World." Montréal: UNESCO.

Wandera, S.O. J. P.M. Ntozi and B. Kwagala, 2010, "Spousal sexual violence, sexual behavior and sexually transmitted infections among evermarried women in Uganda". African Population Studies 24 (I\&2) :70-87

Yount, K.M. and J.S. Carrera. 2006. "Domestic Violence against Married Women in Cambodia." Social Forces 85(I):355-387.

\footnotetext{
${ }^{1}$ The Burkina Faso DHS 2010 was coupled with the MICS and is usually referred at as BFDHS-MICS 2010. As this study has only used the DHS data, we will refer to this survey in this paper as 'BFDHS 2010'.
} 